\title{
Genetic analyses of overfished silver kob Argyrosomus inodorus (Scieanidae) stocks along the southern African coast
}

\author{
Luca Mirimin $^{1 *}$, Sven Kerwath ${ }^{2,3}$, Brett Macey ${ }^{2}$, Stephen J. Lamberth, ${ }^{2,4}$, Paul D. Cowley ${ }^{4}$, \\ Aletta Bester-van der Merwe ${ }^{1}$, Paulette Bloomer ${ }^{5}$ and Rouvay Roodt-Wilding ${ }^{1}$
}

\footnotetext{
1: Molecular Breeding and Biodiversity Research Group, Department of Genetics, Stellenbosch University, JC Smuts Building, van der Bjl Street, Stellenbosch 7600, South Africa

2: Fisheries Research and Development, Department of Agriculture, Forestry and Fisheries, Private Bag X2, Roggebaai, 8012 Cape Town, South Africa

3: Department of Animal Sciences, Stellenbosch University, Private Bag X1, Matieland, 7602, South Africa

${ }^{4}$ : South African Institute for Aquatic Biodiversity, Private Bag 1015, Grahamstown, 6140

5: Molecular Ecology and Evolution Programme, Department of Genetics, University of Pretoria, Private bag X20, Hatfield, Pretoria 0028, South Africa

*: corresponding author. Email: Imirimin@gmail.com, Phone: +27 (0)21 8085833
}

\section{Highlights}

- Population genetic analyses were carried out on silver kob stocks

- Overfished South African stocks showed signatures of genetic bottleneck

- Population differentiation was found between Namibia and South Africa

- Strong gene flow occurs among the three South African stocks

- Fisheries management should be based both on life-history and genetic data

\begin{abstract}
Silver kob (Argyrosomus inodorus) is a sciaenid fish that has been targeted for more than 150 years by commercial and recreational fisheries in the coastal waters of Namibia and South Africa, where four main stocks have been hypothesised. In the present study, recently developed molecular markers were utilized to evaluate levels of genetic diversity and population structuring among such stocks. Moderate levels of genetic diversity and signatures of bottlenecking were found in the South African stocks (South Western Cape,
\end{abstract}


Southern Cape and South Eastern Cape). Significant population genetic differentiation was detected between Namibia and South Africa, but not among the three putative South African stocks, indicating that the main oceanographic barrier for silver kob populations is to be found in the cool-temperate Benguela region, corroborating recent genetic studies. The lack of genetic structuring in South African waters indicates strong gene flow among the 3 South African putative stocks, which are characterized by distinct age and growth patterns. Thus, in order to guarantee a successful recovery of silver kob stocks, genetic findings should be used in conjunction with life-history and behavioural data to tailor future management measures aimed at mitigating the effects of different fisheries throughout the species' distribution range.

\section{Keywords}

Silver kob; Argyrosomus inodorus; microsatellites; overfishing; fisheries management

\section{INTRODUCTION}

Population genetic studies have become an integral component of modern fisheries management, which depends on the understanding of target stocks and their ecosystem (Begg and Waldman, 1999), as well as inherent socio-economic factors (Worm et al., 2009). This is particularly important for overfished species, for which molecular approaches have been increasingly effective in revealing trends of genetic diversity and cryptic stock composition (Hauser and Carvalho, 2008; Pinsky and Palumbi, 2014).

Silver kob (Argyrosomus inodorus Griffiths \& Heemstra 1995) is a sciaenid fish endemic to coastal waters of Namibia and South Africa that has been targeted for more than 150 years by commercial and recreational fisheries (Griffiths, 2000; Holtzhausen et al., 2001; Pappe, 1866). With spawner biomass-per-recruit estimates of $2.9-12.5 \%$ of pre-exploitation levels, South African silver kob stocks have been declared collapsed since the mid-1990s (Griffiths, 1997a). Nonetheless the species remains an important target of commercial line-, gill- and beach-seine fisheries (Griffiths, 2000; Holtzhausen et al., 2001; Lamberth et al., 1997), recreational fishers (Kirchner and Beyer, 1999) and bycatch in other fisheries (Attwood et al., 2011; Hutchings and Lamberth, 2002). Prior to the mid-1990's, the distinction and distribution of silver kob was unclear due to partial geographic overlap with other sciaenid 
species however, based on morphological, behavioural and unique life-history parameters, its taxonomic distinction has since been resolved (Griffiths and Heemstra, 1995). Subsequent studies have shown that silver kob attains sexual maturity between one and three years of age, with males maturing earlier than females (Griffiths, 1996a; Kirchner and Voges, 1999). Spawning behaviour and movement patterns of sexually mature silver kob are determined mainly by temperature-driven oceanographic conditions, with peak spawning taking place in spring-summer following a North-South migration along the Namibian coast (Kirchner and Holtzhausen, 2001) and an inshore-offshore shift in South African waters (Griffiths, 1997b). Eggs and larvae are transported by currents to recruitment and nursery areas $(<50 \mathrm{~m}$ depth), juveniles are found mainly over soft substrata of sand or mud and move to deeper waters (5-120m) as they grow (Griffiths, 1997b; Kirchner and Holtzhausen, 2001).

Investigations on otolith dimensions, fish length, growth rate and tagging led to the conclusion that four main stocks occur throughout the species' distribution range, including one in Namibia (Kirchner and Holtzhausen, 2001; Kirchner and Voges, 1999) and three in South Africa (Griffiths, 1997b). Nonetheless, morphological and growth rate differences may result from phenotypic plasticity related to distinct environmental conditions and diet regimes, and therefore may not be reflective of genetic differences arising from reproductive isolation, as pointed out by Griffiths (1996a). Monitoring trends in catches is complicated by poor compliance to existing regulations including unreported and illegal fishing (e.g. Lamberth et al., 1997; Sauer et al., 1997) and poor coverage in recreational and trawl catch monitoring. Furthermore, the establishment of clear and effective regulations is hampered by the co-occurrence with other morphologically-similar species of the Family Sciaenidae, such as $A$. coronus and A. japonicus (Griffiths, 1996b; Potts et al., 2014; Potts et al., 2010), which may be confounded in the field with A. inodorus (Mirimin et al., 2014). Additionally, due to marketability and desirable traits (such as fast growth), silver kob has been identified as a potential candidate species in the emerging South African aquaculture sector (Bolton et al., 2013), which has led to studies of domestication and performance in captivity (e.g. Ferreira et al., 2008; Yearsley et al., 2011). While increasing aquaculture production may alleviate demand pressure on wild stocks, the poor understanding of the 
genetic structure and connectivity of the postulated stocks inhibits the sustainable development of emerging fish farming practices.

Current management is inconsistent among target and bycatch fisheries and could benefit from the implementation of additional protective regulations tailored to safeguard spawning and recruitment habitats, as well as reproductively isolated populations (Griffiths, 1997a; Kirchner et al., 2001). To date, a recent study has used genetic data to compare silver kob from two localities in South Africa and Namibia, respectively, revealing genetic distinctiveness between these two areas (Henriques et al. 2014). However, a large portion of the species' distribution range has yet to be investigated. Thus, the aim of the present study was to employ recently developed molecular markers to corroborate previous studies and to evaluate levels of genetic diversity and population genetic structuring among the currently recognized silver kob stocks in Namibia and South Africa, as postulated in Griffiths (1997b).

\section{MATERIALS AND METHODS}

A total of 399 wild silver kob were collected between 2002 and 2012 (mostly in 2010) along the Namibian and South African coasts, encompassing all four currently recognized stocks: Namibia (NAM, $n=14$ ), South Western Cape (SWC, $n=182$ ), Southern Cape (SC, $n=82$ ) and South Eastern Cape (SEC, $n=121$ ) (Figure 1)(Table 1). Genomic DNA was extracted from fin tissue by means of a proteinase $\mathrm{K}$ digestion and chloroform extraction method (modified from Mirimin and Roodt-Wilding, 2015). Quantity and quality of extracted DNA were assessed using a NanoDrop ${ }^{\mathrm{TM}}$ ND 1000 spectrophotometer (Thermo Fisher Scientific). Multilocus genotypic data were obtained by amplification of 16 microsatellite markers as per published protocols: Ajap02, Ajap06, Ajap12, Ajap14 (Mirimin et al., 2013), UBA03, UBA05, UBA06, UBA40, UBA42, UBA44, UBA50, UBA851, UBA853, UBA854 (Archangi et al., 2009). Genotyping was conducted on an $\mathrm{ABI} 3730 \mathrm{xl}$ DNA Analyzer and size of amplified DNA fragments was resolved by comparison to GeneScan ${ }^{\mathrm{TM}} 600 \mathrm{LIZ}^{\circledR}$ size standard (Applied Biosystems) with the aid of GeneMapper ${ }^{\circledR} 4$ software (Life Technologies).

The data set was screened for presence of allele irregularities, potential genotyping errors, large allele drop-out and null alleles using the approaches implemented in MICROCHECKER 
Table 1 Details of samples used in the present study. Putative stock (South Western Cape: west of Cape Agulhas; Southern Cape: between Cape Agulhas and Cape St. Francis; South Eastern Cape: east of Cape St. Francis), name of sampling/landing location (n: number of individuals), period of capture and coordinates of approximate location of capture are reported. n.a.: not available.

\begin{tabular}{|c|c|c|c|}
\hline Stock (n) & Location (n) & $\begin{array}{l}\text { Period of } \\
\text { capture }\end{array}$ & Latitude / Longitude \\
\hline Namibia (14) & Swakopmund (14) & Jul ‘02 & $-22.672182 / 14.511137$ \\
\hline $\begin{array}{l}\text { South Western } \\
\text { Cape (182) }\end{array}$ & $\begin{array}{l}\text { Rietfontein (20) } \\
\text { Berg River (18) } \\
\text { Langebaan (9) } \\
\text { False Bay (14) } \\
\text { Sant Helena Bay (5) } \\
\text { Saldanha (59) } \\
\text { Muizenberg (16) } \\
\text { Strandfontein (41) }\end{array}$ & $\begin{array}{l}\text { Mar '02 } \\
\text { May '09 } \\
\text { Jan '10 - Sep '10 } \\
\text { May '10 } \\
\text { Aug '10 } \\
\text { Sep '10 } \\
\text { Oct '10 } \\
\text { Apr '11 }\end{array}$ & $\begin{array}{l}\text { n.a. } \\
-32.6968 \text { / } 18.2286 \\
-33.02255 \text { / } 18.02895 \\
-34.07327 \text { / } 18.66793 \\
-32.6968 \text { / } 18.2286 \\
-33.02255 \text { / } 18.02895 \\
-34.10777 \text { / } 18.4717 \\
-34.08889 \text { / 18.576984 }\end{array}$ \\
\hline $\begin{array}{l}\text { Southern Cape } \\
\text { (82) }\end{array}$ & $\begin{array}{l}\text { Struis Bay (9) } \\
\text { Stil Bay (33) } \\
\text { Mossel Bay (35) } \\
\text { Ellen Khuzwayo (5) }\end{array}$ & $\begin{array}{l}\text { Jan '10 - May '10 } \\
\text { Apr '10 - jun '10 } \\
\text { May'10 - Jun '10 } \\
\text { May '10 }\end{array}$ & $\begin{array}{l}-34.82085 \text { / } 20.099483 \\
-34.41455 \text { / } 21.63505 \\
-34.141095 / 22.301559 \\
-34.56765 \text { / } 20.404367\end{array}$ \\
\hline $\begin{array}{l}\text { South Eastern } \\
\text { Cape (121) }\end{array}$ & $\begin{array}{l}\text { Algoa Bay (21) } \\
\text { Port Alfred (69) } \\
\text { Beacon (11) } \\
\text { Sand Rock (15) } \\
\text { Road Mark (1) } \\
\text { Rondebos (2) } \\
\text { Port Elizabeth (2) }\end{array}$ & $\begin{array}{l}\text { Sep '02 } \\
\text { Feb '10 - Feb '11 } \\
\text { Mar'10 - Dec '10 } \\
\text { May '10 } \\
\text { May'10 } \\
\text { May'10 } \\
\text { Sep '10 }\end{array}$ & $\begin{array}{l}-33.812849 \text { / } 26.011505 \\
-33.653227 / 26.928177 \\
-33.65005 / 26.8423 \\
-33.641683 \text { / } 26.8267 \\
-33.64587 \text { / } 26.894983 \\
-33.56925 \text { / 27.093217 } \\
-33.928619 \text { / 25.924988 }\end{array}$ \\
\hline
\end{tabular}




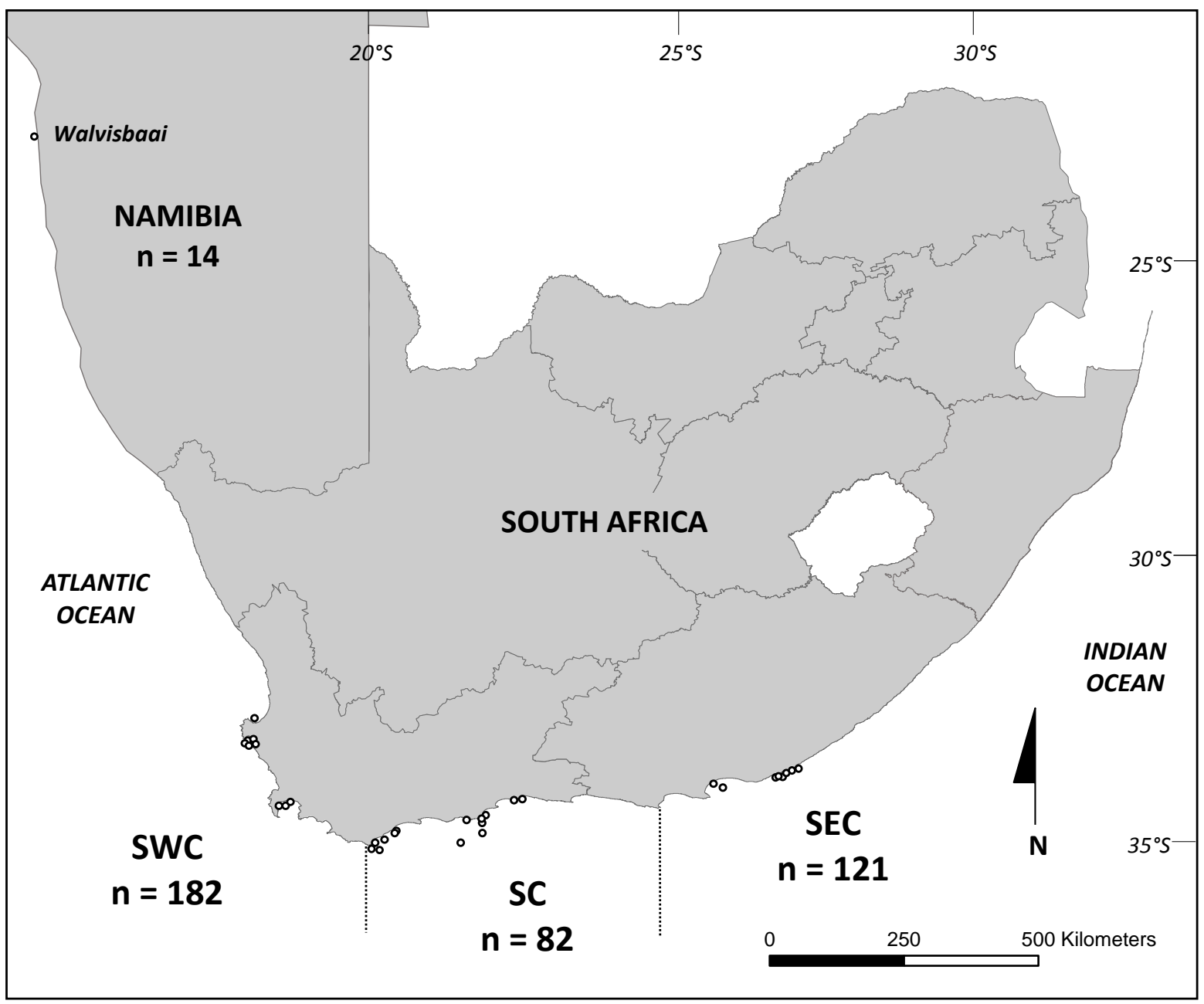

Figure 1 Sampling locations (open circles) of silver kob for from the four currently recognized stocks in Namibia, South Western Cape (SWC), Southern Cape (SC) and South Eastern Cape (SEC).

2.2.3 (1000 randomizations and Bonferroni-adjusted 95\% confidence intervals)(van Oosterhout et al., 2004). Descriptive statistics including number of alleles, allelic richness, expected and observed heterozygosity, as well as tests for Hardy-Weinberg equilibrium (Exact test using a Markov chain of 1000000 and 100000 de-memorization steps) were calculated using ARLEQUIN 3.5.1.2 (Excoffier and Lischer, 2010). Linkage disequilibrium between pairs of loci and estimation of $F_{I S}$ were calculated as implemented in FSTAT 2.9.3.2 (Goudet, 2001). Correction for multiple comparisons was applied following a sequential Bonferroni procedure (Holm, 1979).

The power to detect population structuring using the microsatellite markers and sample sizes from the present study (South African samples only) was evaluated using POWSIM 4.1 
(simulation details: 100000 iterations, 1000 replicates, $N_{e}=755-4814$, Generations $(t)=0$ $\left.20, F_{S T}=0.005,0.0025,0.001\right)$ (Ryman and Palm, 2006). Population structure analyses were carried out with ARLEQUIN 3.5.1.2 by means of a locus-by-locus AMOVA, using the sum of squared size differences $\left(R_{S T}\right)$ method. The same program was used to calculate pairwise $F_{S T}$ (number of different alleles), $\mathrm{R}_{\mathrm{ST}}$ (sum of squared size differences) and relative significance levels (1023 permutations). Population structure was also investigated using a Bayesian approach with and without taking into account information on sampling location using STRUCTURE 2.3.1 (Pritchard et al., 2000). Markov Chain Monte Carlo (MCMC) simulations were carried out for three independent MCMC runs (100000 burn-in and 1000000 iterations) for values of $\mathrm{K}$ ranging from 1 to 4 , using the admixture model. Isolation-bydistance (IBD) was investigated by means of a Mantel test between linear genetic distance and geographic distance (999 permutations) using GENALEX 6.5 (Peakall and Smouse, 2006; Peakall and Smouse, 2012).

In order to detect potential signatures of recent reduction of effective population size (genetic bottlenecking), observed levels of gene diversity were compared to values expected in equilibrium population using the heterozygosity excess approach (1000 simulations) as implemented in the program BOTTLENECK 1.2.02 (Cornuet and Luikart, 1996). For this test, the Infinite Allele Model (IAM), the Stepwise Mutation Model (SMM), and the Two-Phase Model (TPM) of mutation were implemented with 95\% single-step mutations and 5\% multiple-step mutations, with a variance among multiple steps set to 12 (as suggested in Piry et al., 1999). Estimates of contemporary effective population size ( $\mathrm{Ne})$ and $95 \%$ confidence intervals (jackknifing over loci) were calculated using a single-step estimator LDNe (Waples and Do, 2010), as implemented in NeESTIMATOR 2 (Do et al., 2014). For this test $\mathrm{N}_{\mathrm{e}}$ estimates were calculated with and without rare alleles (critical frequency threshold value of 0.02 ) and assuming random mating.

To test for potential genetic patterns between sexes, a number of genetic estimators (allelic richness, observed heterozygosity, gene diversity, $F_{I S}, F_{S T}$, relatedness and corrected relatedness) were calculated and compared between selected groups of males and females from each of the three South African regions using FSTAT (1000 permutations). The sample sizes used for this test were as follows: SWC (66 males, 78 females), SC (23 males, 36 
females) and SEC (27 males, 43 females). For this test, no Namibian samples were included due to limited sample size.

\section{RESULTS}

All 16 microsatellite markers showed negligible levels of genotyping errors and no evidence of linkage disequilibrium was detected between any pair of loci. Two markers (Ajap12 and UBA853) showed potential presence of null alleles, hence subsequent data analyses were performed with the remaining 14 markers. Levels of genetic diversity were moderate in both the South African and Namibian samples, with comparable allelic richness estimates, but with the former region showing lower heterozygosity than the latter region (Table 2). No evidence of deviation from expected Hardy-Weinberg proportions or inbreeding were

Table 2 Descriptive statistics averaging over 14 loci (with standard deviation in parentheses), bottleneck test (Wilcoxon test) and estimates of effective population size $\left(L_{D} N_{e}\right)$ in the entire South African and Namibian sample sets, as well as the South Western Cape (SWC), Southern Cape (SC) and South Eastern Cape (SEC). ${ }^{*}$ : $p<0.05$; ${ }^{\text {ns}}$ : not significant; Inf: large, but not possible to estimate a precise value.

\begin{tabular}{|c|c|c|c|c|c|}
\hline & Namibia & South Africa & SWC & SC & SEC \\
\hline $\begin{array}{l}n \\
N_{A} \\
A_{R} \\
H_{0} \\
H_{E} \\
F_{I S}\end{array}$ & $\begin{array}{l}14 \\
7.4(2.6) \\
6.7(2.1) \\
0.793(0.165) \\
0.775(0.115) \\
-0.023^{\mathrm{ns}}\end{array}$ & $\begin{array}{l}385 \\
13.9(6.1) \\
6.4(2.7) \\
0.681(0.215) \\
0.698(0.210) \\
0.024^{\star}\end{array}$ & $\begin{array}{l}182 \\
12.3(5.4) \\
6.4(2.7) \\
0.686(0.221) \\
0.697(0.218) \\
0.015^{\text {ns }}\end{array}$ & $\begin{array}{l}82 \\
11.3(4.9) \\
6.4(2.6) \\
0.667(0.239) \\
0.697(0.211) \\
0.043^{\text {ns }}\end{array}$ & $\begin{array}{l}121 \\
11.4(4.9) \\
6.4(2.7) \\
0.687(0.199) \\
0.703(0.199) \\
0.022^{\text {ns }}\end{array}$ \\
\hline $\begin{array}{r}\text { Wilcoxon test } \\
\text { IAM } \\
\text { TPM } \\
\text { SMM }\end{array}$ & $\begin{array}{l}\text { ns } \\
\text { ns } \\
\text { ns }\end{array}$ & $\begin{array}{l}\text { ns } \\
<0.01 \\
<0.001\end{array}$ & $\begin{array}{l}\text { ns } \\
\text { ns } \\
<0.01\end{array}$ & $\begin{array}{l}\text { ns } \\
<0.05 \\
<0.001\end{array}$ & $\begin{array}{l}\text { ns } \\
\text { ns } \\
<0.01\end{array}$ \\
\hline \multicolumn{6}{|l|}{$\operatorname{LDN}_{e}$} \\
\hline $\begin{array}{l}\text { P crit } 0.02(95 \% \mathrm{Cl}) \\
\text { P crit } 0.00(95 \% \mathrm{Cl})\end{array}$ & $\begin{array}{l}\operatorname{Inf}(102.2-\operatorname{Inf}) \\
\operatorname{Inf}(102.2-\operatorname{Inf})\end{array}$ & $\begin{array}{l}1346.6(755.1- \\
4813.8) \\
1097.7(606.9- \\
4045.2)\end{array}$ & $\begin{array}{l}451.9(291.9- \\
915.8) \\
394.0(245.6- \\
871.4)\end{array}$ & $\begin{array}{l}998.3 \text { (323. - } \\
\text { Inf) } \\
489.8(239.9- \\
13416.0)\end{array}$ & $\begin{array}{l}\operatorname{Inf}(758.3-\operatorname{lnf}) \\
\operatorname{Inf}(947.1-\operatorname{lnf})\end{array}$ \\
\hline
\end{tabular}

$\mathrm{n}$ : number of individuals; $\mathrm{N}_{\mathrm{A}}$ : number of alleles; $\mathrm{A}_{\mathrm{R}}$ : allelic richness calculated over a minimum of ten individuals; $\mathrm{H}_{\mathrm{O}}$ : observed heterozygosity; $\mathrm{H}_{\mathrm{E}}$ : expected heterozygosity; $\mathrm{F}_{\mathrm{IS}}$ : inbreeding coefficient; Wilcoxon test: test statistic to detect bottleneck signatures under the infinite- (IAM), Two-phase(TPM) and stepwise mutation models (SMM); $\mathrm{LDN}_{\mathrm{e}}$ : estimates of effective population size using the Linkage Disequilibrium method. 
detected, with the exception of the combined South African sample, which showed a marginally significant inbreeding coefficient $\left(F_{I S}=0.024, P<0.05\right)$ (Table 2). Signatures of population bottlenecking were detected in the South African samples, but not in Namibia for which a limited sample size was available (Table 2). Effective population size $\left(\mathrm{N}_{\mathrm{e}}\right)$ estimates with or without excluding rare alleles (frequency less than 0.02) are shown in Table 2. These results indicated a number of effective breeders of 1346.6 (755.1 - 4813.8) along the South African coast, with the SWC showing the lowest estimates (less than 1000) compared to other sampled stocks. Despite the inclusion in this analysis, the Namibian sample should be deemed too small to provide reliable estimates (Table 2).

Power tests (POWSIM) showed that the markers and sample sizes used in the present study were effective at detecting significant population structuring at the level of $\mathrm{F}_{\mathrm{ST}}=0.0066$, indicating the ability of such markers to investigate subtle genetic structuring. AMOVA analyses revealed that most genetic variation resided within stocks (93.23\%), with the remaining variation mainly due to differences between the Namibian and South African regions (6.9\%). Genetic structuring analyses using the Bayesian approach (STRUCTURE) could identify significant structuring only when taking into account sampling location as prior, but not without such prior. Highest likelihood estimates were obtained for $K=2$, with the two clusters being represented by Namibian and South African individuals, respectively. Pairwise $\mathrm{F}_{\mathrm{ST}}$ estimates corroborated previous results indicating significant differentiation between all South African samples and the Namibian sample, but not among stocks within South African waters (Table 3). Testing for isolation-by-distance revealed a significant correlation $(P=0.001)$ between genetic distance and geographic distance and a low positive slope for both the overall sample $\left(R^{2}=0.0083\right)$ as well as for the South African sample (i.e. South African samples only) $\left(R^{2}=0.0027\right)$. No significant differences between sexes were found for any of the estimators calculated, with the exception of observed heterozygosity (higher in females than males, $\mathrm{P}<0.05$ ) and within group gene diversity (higher in females than males, $P<0.01$ ). Although the latter finding suggests that female may disperse more than males, this hypothesis should be further investigated with additional genetic and behavioural data. 
Table 3. Pairwise $F_{S T}$ (below diagonal) and $R_{S T}$ (above diagonal) values among silver kob samples from Namibia (NAM), South Western Cape (SWC), Southern Cape (SC) and South Eastern Cape (SEC) of South Africa. ${ }^{* * *}: p<0.001,{ }^{* *}$ : $p<$ 0.01 , ns: not significant.

\begin{tabular}{lllll}
\hline & NAM & SWC & SC & SEC \\
NAM & & $0.059^{\star \star \star}$ & $0.072^{\star \star \star}$ & $0.044^{\star \star}$ \\
SWC & $0.043^{\star \star \star}$ & $-0.002^{\text {ns }}$ & $0.000^{\text {ns }}$ \\
SC & $0.055^{\star \star \star}$ & $-0.004^{\text {ns }}$ & $-0.003^{\text {ns }}$ \\
SEC & $0.030^{\star \star \star}$ & $-0.001^{\text {ns }}$ & $-0.003^{\text {ns }}$ & \\
\hline
\end{tabular}

\section{DISCUSSION}

Levels of genetic diversity tended to be lower in South African stocks than Namibian kob, for which no bottleneck signatures were detected. Despite the limited sample availability of the Namibian stock, estimates of heterozygosity are similar to those reported in a recent genetic study that used smaller number of markers but higher number of samples from Namibia (Henriques et al., 2014b). In contrast, levels of heterozygosity found in the present study were lower than those reported for the same species in Henriques et al. (2014b) for the same area. In South Africa, where sampling was more comprehensive, levels of genetic diversity were comparable to other sciaenid species affected by strong fishing pressure (Archangi et al., 2009; Gold and Turner, 2002; Haffray et al., 2012). Comparisons between observed levels of genetic diversity and those expected in populations at equilibrium (bottleneck tests) indicated that South African stocks have suffered a demographic decline in the past decades. This is in agreement with the critically low spawner biomass-per-recruit estimates (Booth and Hecht, 1998; Griffiths, 1997a) and declining catches reported in the 1990's (Booth and Hecht, 1998; Griffiths, 1997a). These findings may be reflective of lesser fishing pressure in Namibian waters compared to South Africa. Despite a recent study showing some recovery of South African silver kob, possibly due to forced fishing effort reductions since 2000 (Winker et al., 2013), the species remains a by-catch of demersal trawl fisheries (Attwood et al., 2011). Bottleneck signatures were stronger in the SWC stock, which could be a reflection of differential fishing pressure in this region by certain fisheries such as gillnet (Hutchings and Lamberth, 2003). In Namibia, the impact of commercial fisheries is in contrast to recreational fisheries because different demographic fractions of the local stock are targeted by each fishery type, respectively (Stage, 2006). However, 
among other limitations of such tests, the power of detecting population bottlenecks can be hampered by low number of markers and sample sizes (8-9 loci and 31-38 individuals) (Peery et al., 2012). Although number of markers and sample sizes can be deemed appropriate in the present study (with the exception of the Namibian sample), in order to fully evaluate the impact of fishing pressure on levels of genetic diversity, the inclusion of additional marker types (such as slow evolving mitochondrial DNA genes) and temporal sampling would help disentangling the effect of contemporary and historical demographic processes (e.g. founder effects and historical bottlenecks following colonization) (e.g. Grant and Bowen, 1998). Furthermore, a range of biotic and abiotic factors can play significant roles in shaping levels of genetic variation in marine fish populations (Hardie et al., 2006), thus genetic data should be corroborated by other demographic and environmental information. Nonetheless, these findings and future monitoring of genetic diversity will be increasingly important in silver kob management because prolonged fishing pressure will not only affect abundance, but also the evolutionary and adaptive potential of targeted stocks (Jørgensen et al., 2007; Pinsky and Palumbi, 2014). In fact, a significant decrease in mean length of silver kob has been reported during the last century, with potential trophodynamic implications for the entire ecosystem (Yemane et al., 2004).

Analyses of effective population size $\left(\mathrm{N}_{\mathrm{e}}\right)$ carried out in the present study revealed an effective number of breeders in the order of thousands over a large geographical range and covering most of the species' distribution range. This is not uncommon in marine fish populations (Hauser and Carvalho, 2008), as it has also been recently found in another overfished South African sciaenid species (Mirimin et al., 2015). A recent genetic study comparing nuclear and mitochondrial data from two locations in Namibia and South Africa, respectively, suggested that the shallow but significant population structure found between these two regions is the result of limited number of migrants and historically large population sizes (Henriques et al., 2014b). Nonetheless, the accuracy of $\mathrm{N}_{\mathrm{e}}$ estimates depends from many factors deriving from the underlying complexity of the studied populations and should be treated with caution (Fraser et al., 2007; Hare et al., 2011; Neel et al., 2013; Palstra and Ruzzante, 2011). However, such estimates can be informative tools for fisheries management, especially in monitoring trends of genetic variance in species of ecological and commercial importance (Hauser and Carvalho, 2008; Pinsky and Palumbi, 
2014). This study provides the first genetic evaluation of the three main South African silver kob stocks, which can be used as baseline data for future studies aimed at monitoring demographic trends and effectiveness of management actions in the studied areas.

Population genetic structure analyses revealed significant segregation between Namibian and South African populations, with levels of nuclear genetic distinctiveness similar to those reported in a recent genetic study (Henriques et al., 2014b). These findings are in agreement with previous studies that not only showed differences in growth patterns (Kirchner and Voges, 1999), but also confirmed that migratory movements between these geographically distant areas are very limited (Kirchner and Holtzhausen, 2001). At the beginning of each summer, adult Namibian silver kob migrates outward to common spawning grounds in Sandwich and Meob Bays, followed by a northward migration back to feeding areas in Skeleton Coast Park when temperatures drop below $15^{\circ} \mathrm{C}$ (Kirchner \& Holtzhousen 2001). Concentrations of silver kob in South African waters also appear to be driven by temperature, with inshore-offshore shifts occurring between summer and winter in order to occupy the preferred temperature range of $13-16^{\circ} \mathrm{C}$ (Griffiths, $\left.1997 \mathrm{~b}\right)$. This indicates that the main oceanographic boundary between populations of silver kob is to be found in the cool temperate conditions of the Benguela current along the Atlantic coast of South Africa. The Benguela's perennial upwelling cold water system located off Namibia has also been identified as the main barrier to gene flow in another warm-temperate sciaenid species Atractoscion aequidens (Henriques et al., 2014a) and between South African and Angolan stocks of the coastal Lichia amia (Henriques et al., 2012). Nevertheless, contrasting mitochondrial population genetic structuring patterns have been found in the two Cape hake species co-occurring in Namibian and South African waters, with Merluccius capensis showing no genetic differentiation, while adult (3-4 years old) M. paradoxus showing significant segregation between these two main regions (von der Heyden et al., 2007). Such inconsistent patterns of population structuring among marine fish species co-occurring in the Benguela system indicate that differences in life-history and behaviour play a significant role in dispersal potential and gene flow of pelagic and demersal fish species.

The effect of temporal and life-history (spawning) parameters on inter- and intra-annual variation in population structuring were only marginally covered in this study. This is mostly due to the opportunistic nature of samples used in the present study, which yet resulted 
from a substantial sampling collection effort, considering the large geographical area covered and the marine habitat of the species under study. In fact, it was not possible to carry out direct comparisons between stocks exclusively during spring-summer when spawning takes place. If mixing of distinct genetic stocks occurred during the non-spawning time, this should have been identified by the Bayesian (STRUCTURE) approach, though this could have been confounded in the case of a weak but significant isolation-by-distance pattern of population structuring. Additionally, although most samples used in the present study were collected in 2010, only some samples (including the Namibian sample) were collected as far back as 2002, thus testing for temporal stability of population structuring would require additional sampling effort in the future. The lack of genetic differentiation within South African waters is in contrast with findings in previous studies that identified at least three distinct stocks based on age and growth data (Griffiths, 1996a). Although morphological differences indicate some level of segregation among South African stocks, genetic findings indicate that gene flow is strong enough to counteract the potential segregating effects of genetic drift. Tagging data from South African waters indicate that silver kob show strong site fidelity, but are capable of occasional long distance movements (Griffiths, 1997b). In Namibia, Kirchner and Holtzhausen (2001) suggested that only large fish $(>68 \mathrm{~cm})$ take part in the spawning migration, despite the presence of mature individuals at smaller size classes. It is not known if this is the case in South African waters, but the cooland warm-temperate provinces of South Africa are subject to seasonal fluctuations (Demarcq et al., 2003), which may lead to prolonged spawning periods and possibly overlapping spawning areas, hence enhancing gene flow among adjacent stocks. Several oceanographic barriers to gene flow have been identified around the African coastline (Teske et al., 2011 and references therein), however in the case of silver kob it appears that the three putative South African stocks are strongly connected, with the main barrier to gene flow located between the South African west coast and Namibia. From a fishery management perspective, it is important to consider variation in both phenotypic and genetic components, since they are affected by selective and stochastic processes that determine the future of diverging populations (Winker, 2009). As also argued by Griffiths (1997b), the different life-history traits of silver kob in the three putative South African stocks indicate that such aggregations are likely to respond differently to fishing pressure and therefore should be managed accordingly. Thus, in order to guarantee a successful 
recovery of silver kob stocks, genetic findings should be used in conjunction with life-history data to tailor future management measures aimed at mitigating the effects of different fisheries throughout the species' distribution range.

\section{Acknowledgements}

The authors are grateful to anonymous reviewers for improving previous versions of this manuscript, DAFF for financial supportand the Central Analytical Facility DNA sequencing unit (http://www.sun.ac.za/CAF) for genotyping.

\section{References}

Archangi, B., Chand, V., Mather, P.B., 2009. Isolation and characterization of 15 polymorphic microsatellite DNA loci from Argyrosomus japonicus (mulloway), a new aquaculture species in Australia. Molecular Ecology Resources 9, 412-414.

Attwood, C.G., Petersen, S.L., Kerwath, S.E., 2011. Bycatch in South Africa's inshore trawl fishery as determined from observer records. ICES Journal of Marine Science 68, 2163-2174.

Begg, G.A., Waldman, J.R., 1999. An holistic approach to fish stock identification. Fisheries Research 43, 35-44.

Bolton, J.J., Davies-Coleman, M.T., Coyne, V.E., 2013. Innovative processes and products involving marine organisms in South Africa. African Journal of Marine Science 35, 449-464.

Booth, A.J., Hecht, T., 1998. Changes in the Eastern Cape demersal inshore trawl fishery between 1967 and 1995. South African Journal of Marine Science 19, 341-353.

Cornuet, J.-M., Luikart, G., 1996. Description and power analysis of two tests for detecting recent population bottlenecks from allele frequency data. Genetics 144, 2001-2014.

Demarcq, H., Barlow, R.G., Shillington, F.A., 2003. Climatology and variability of sea surface temperature and surface chlorophyll in the Benguela and Agulhas ecosystems as observed by satellite imagery. African Journal of Marine Science 25, 363-372.

Do, C., Waples, R.S., Peel, D., Macbeth, G.M., Tillett, B.J., Ovenden, J.R., 2014. NeEstimator v2: reimplementation of software for the estimation of contemporary effective population size ( $\mathrm{Ne}$ ) from genetic data. Molecular Ecology Resources 14, 209-214.

Excoffier, L., Lischer, H.E.L., 2010. Arlequin suite ver 3.5: A new series of programs to perform population genetics analyses under Linux and Windows. Molecular Ecology Resources 10, 564567.

Ferreira, H.L., Vine, N.G., Griffiths, C.L., Kaiser, H., 2008. Effect of salinity on growth of juvenile silver kob, Argyrosomus inodorus (Teleostei: Sciaenidae). African Journal of Aquatic Science 33, 161165. 
Fraser, D.J., Hansen, M.M., Østergaard, S., Tessier, N., Legault, M., Bernatchez, L., 2007. Comparative estimation of effective population sizes and temporal gene flow in two contrasting population systems. Molecular Ecology 16, 3866-3889.

Gold, J., Turner, T., 2002. Population structure of red drum (Sciaenops ocellatus) in the northern Gulf of Mexico, as inferred from variation in nuclear-encoded microsatellites. Marine Biology 140, 249-265.

Goudet, J., 2001. FSTAT, a program to estimate and test gene diversities and fixation indices (version 2.9.3). Available at http://www.unil.ch/izea/softwares/fstat.html.

Grant, W.A.S., Bowen, B.W., 1998. Shallow population histories in deep evolutionary lineages of marine fishes: insights from sardines and anchovies and lessons for conservation. Journal of Heredity 89, 415-426.

Griffiths, M.H., 1996a. Age and growth of South African silver kob Argyrosomus inodorus (Sciaenidae), with evidence for separate stocks. South African Journal of Marine Science 17, 3748.

Griffiths, M.H., 1996b. Life history of the dusky kob Argyrosomus japonicus (Sciaenidae) off the east coast of South Africa. South African Journal of Marine Science 17, 135-154.

Griffiths, M.H., 1997a. The application of per-recruit models to Argyrosomus inodorus, an important South African sciaenid fish. Fisheries Research 30, 103-115.

Griffiths, M.H., 1997b. The life history and stock separation of silver kob, Argyrosomus inodorus, in South African waters. Fishery Bulletin 95, 47-67.

Griffiths, M.H., 2000. Long-term trends in catch and effort of commercial linefish off South Africa's Cape Province: snapshots of the 20th century. South African Journal of Marine Science 22, 81110.

Griffiths, M.H., Heemstra, P.C., 1995. A contribution to the taxonomy of the marine fish genus Argyrosomus (Perciforrnes: Sciaenidae), with descriptions of two new species from southern Africa. Ichthyol. Bull. J. L. B. Smith Inst. Ichlhyol. 65, 40.

Haffray, P., Malha, R., Ould Taleb Sidi, M., Prista, N., Hassan, M., Castelnaud, G., Karahan-Nomm, B., Gamsiz, K., Sadek, S., Bruant, J.-S., Balma, P., Bonhomme, F., 2012. Very high genetic fragmentation in a large marine fish, the meagre Argyrosomus regius (Sciaenidae, Perciformes) : impact of reproductive migration, oceanographic barriers and ecological factors. Aquat. Living Resour. 25, 173-183.

Hardie, D.C., Gillett, R.M., Hutchings, J.A., 2006. The effects of isolation and colonization history on the genetic structure of marine-relict populations of Atlantic cod (Gadus morhua) in the Canadian Arctic. Canadian Journal of Fisheries and Aquatic Sciences 63, 1830-1839.

Hare, M.P., Nunney, L., Schwartz, M.K., Ruzzante, D.E., Burford, M., Waples, R.S., Ruegg, K., Palstra, F., 2011. Understanding and Estimating Effective Population Size for Practical Application in Marine Species Management. Conservation Biology 25, 438-449.

Hauser, L., Carvalho, G.R., 2008. Paradigm shifts in marine fisheries genetics: ugly hypotheses slain by beautiful facts. Fish and Fisheries 9, 333-362.

Henriques, R., Potts, W.M., Santos, C.V., Sauer, W.H.H., Shaw, P.W., 2014a. Population Connectivity and Phylogeography of a Coastal Fish, Atractoscion aequidens (Sciaenidae), across the Benguela Current Region: Evidence of an Ancient Vicariant Event. PLoS ONE 9, e87907.

Henriques, R., Potts, W.M., Sauer, W.H.H., Shaw, P.W., 2012. Evidence of deep genetic divergence between populations of an important recreational fishery species, Lichia amia L. 1758, around southern Africa. African Journal of Marine Science 34, 585-591.

Henriques, R., Potts, W.M., Sauer, W.H.H., Shaw, P.W., 2014b. Incipient genetic isolation of a temperate migratory coastal sciaenid fish (Argyrosomus inodorus) within the Benguela Cold Current system. Marine Biology Research, 1-7.

Holm, S., 1979. A simple sequentially rejective multiple test procedure Scandinavian Journal of Statistics 6, 65-70. 
Holtzhausen, J.A., Kirchner, C.H., Voges, S.F., 2001. Observations on the linefish resources of Namibia, 1990-2000, with special reference to West Coast steenbras and silver kob. South African Journal of Marine Science 23, 135-144.

Hutchings, K., Lamberth, S.J., 2002. Bycatch in the gillnet and beach-seine fisheries in the Western Cape, South Africa, with implications for management. South African Journal of Marine Science 24, 227-241.

Hutchings, K., Lamberth, S.J., 2003. The likely impacts of an eastward expansion of the inshore gillnet fishery in the Western Cape, South Africa: implications for management. Marine and Freshwater Research 54, 39-56.

Jørgensen, C., Enberg, K., Dunlop, E.S., Arlinghaus, R., Boukal, D.S., Brander, K., Ernande, B., Gårdmark, A.G., Johnston, F., Matsumura, S., Pardoe, H., Raab, K., Silva, A., Vainikka, A., Dieckmann, U., Heino, M., Rijnsdorp, A.D., 2007. Managing Evolving Fish Stocks. Science 318, 1247-1248.

Kirchner, C.H., Beyer, J.E., 1999. Estimation of total catch of silver kob Argyrosomus inodorus by recreational shore-anglers in Namibia using a roving-roving creel survey. South African Journal of Marine Science 21, 191-199.

Kirchner, C.H., Holtzhausen, J.A., 2001. Seasonal movements of silver kob, Argyrosomus inodorus, (Griffiths and Heemstra) in Namibian waters. Fisheries Management and Ecology 8, 239-251.

Kirchner, C.H., Holtzhausen, J.A., Voges, S.F., 2001. Introducing size limits as a management tool for the recreational line fishery of silver kob, Argyrosomus inodorus (Griffiths and Heemstra), in Namibian waters. Fisheries Management and Ecology 8, 227-237.

Kirchner, C.H., Voges, S.F., 1999. Growth of Namibian silver kob Agyrosomus inodorus based on otoliths and mark-recapture data. South African Journal of Marine Science 21, 201-209.

Lamberth, S.J., Sauer, W.H.H., Mann, B.Q., Brouwer, S.L., Clark, B.M., Erasmus, C., 1997. The status of the South African beach-seine and gill-net fisheries. South African Journal of Marine Science 18, 195-202.

Mirimin, L., Kerwath, S.E., Macey, B.M., Bester-van der Merwe, A.E., Lamberth, S.J., Bloomer, P., Roodt-Wilding, R., 2014. Identification of naturally occurring hybrids between two overexploited sciaenid species along the South African coast. Molecular Phylogenetics and Evolution 76, 30-33.

Mirimin, L., Macey, B.M., Kerwath, S.E., Lamberth, S.J., Bester-van der Merwe, A.E., Cowley, P.D., Bloomer, P., Roodt-Wilding, R., 2015. Genetic analyses reveal declining trends and low effective population size in an overfished South African sciaenid species, the dusky kob (Argyrosomus japonicus). Marine and Freshwater Research.

Mirimin, L., Roodt-Wilding, R., 2015. Testing and validating a modified CTAB DNA extraction method to enable molecular parentage analysis of fertilized eggs and larvae of an emerging South African aquaculture species, the dusky kob (Argyrosomus japonicus). Journal of Fish Biology 86, 12181223.

Mirimin, L., Ruiz Guajardo, J.C., Vervalle, J., Bester-Van der Merwe, A., Kerwath, S., Macey, B., Bloomer, P., Roodt-Wilding, R., 2013. Isolation and validation of microsatellite markers from a depleted South African sciaenid species, the dusky kob (Argyrosomus japonicus), by means of the FIASCO/454 approach. Conservation Genetics Resources 5, 841-844.

Neel, M.C., McKelvey, K., Ryman, N., Lloyd, M.W., Short Bull, R., Allendorf, F.W., Schwartz, M.K., Waples, R.S., 2013. Estimation of effective population size in continuously distributed populations: there goes the neighborhood. Heredity 111, 189-199.

Palstra, F.P., Ruzzante, D.E., 2011. Demographic and genetic factors shaping contemporary metapopulation effective size and its empirical estimation in salmonid fish. Heredity $107,444-$ 455.

Pappe, L., 1866. Synopsis of the edible fishes of the Cape of Good Hope. Brittain, Cape Town. 23pp, Brittain, Cape Town.

Peakall, R., Smouse, P.E., 2006. GenAlEx 6: genetic analysis in Excel. Population genetic software for teaching and research. Molecular Ecology Resources 6, 288-295. 
Peakall, R., Smouse, P.E., 2012. GenAlEx 6.5: genetic analysis in Excel. Population genetic software for teaching and research - an update. Bioinformatics 28, 2537-2539.

Peery, M.Z., Kirby, R., Reid, B.N., Stoelting, R., Doucet-Beer, E., Robinson, S., VÁsquez-Carrillo, C., Pauli, J.N., Palsbøll, P.J., 2012. Reliability of genetic bottleneck tests for detecting recent population declines. Molecular Ecology 21, 3403-3418.

Pinsky, M.L., Palumbi, S.R., 2014. Meta-analysis reveals lower genetic diversity in overfished populations. Molecular Ecology 23, 29-39.

Piry, S., Luikart, G., Cornuet, J.-M., 1999. BOTTLENECK: a computer program for detecting recent reductions in the effective population size using allele frequency data. Journal of Heredity 90 , 502-503.

Potts, W.M., Henriques, R., Santos, C.V., Munnik, K., Ansorge, I., Dufois, F., Booth, A.J., Kirchner, C.H., Sauer, W.H.H., Shaw, P.W., 2014. Ocean warming, a rapid distributional shift, and the hybridization of a coastal fish species. Global Change Biology 20, 2765-2777.

Potts, W.M., Sauer, W.H., Henriques, R., Sequesseque, S., Santos, C.V., Shaw, P.W., 2010. The biology, life history and management needs of a large sciaenid fish, Argyrosomus coronus, in Angola. African Journal of Marine Science 32, 247-258.

Pritchard, J.K., Stephens, M., Donnelly, P., 2000. Inference of population structure using multilocus genotype data. Genetics 155, 945-959.

Ryman, N., Palm, S., 2006. POWSIM: a computer program for assessing statistical power when testing for genetic differentiation. Molecular Ecology Resources 6, 600-602.

Sauer, W.H.H., Penney, A.J., Erasmus, C., Mann, B.Q., Brouwer, S.L., Lamberth, S.J., Stewart, T.J., 1997. An evaluation of attitudes and responses to monitoring and management measures for the South African boat-based linefishery. South African Journal of Marine Science 18, 147-163.

Stage, J., 2006. Optimal harvesting in an age-class model with age-specific mortalities: an example from Namibian linefishing. Natural Resource Modeling 19, 609-631.

Teske, P.R., von der Heyden, S., McQuaid, C.D., Barker, N.P., 2011. A review of marine phylogeography in southern Africa. South African Journal of Science 107, 43-53.

van Oosterhout, C., Hutchinson, W.F., Willis, D.P.M., Shipe, P., 2004. MICRO-CHECKER: software for identifying and correcting genotyping errors in microsatellite data. Molecular Ecology Notes 4, 536-538.

von der Heyden, S., Lipinski, M.R., Matthee, C.A., 2007. Mitochondrial DNA analyses of the Cape hakes reveal an expanding, panmictic population for Merluccius capensis and population structuring for mature fish in Merluccius paradoxus. Molecular Phylogenetics and Evolution 42, 517-527.

Waples, R.S., Do, C., 2010. Linkage disequilibrium estimates of contemporary $\mathrm{N}_{\mathrm{e}}$ using highly variable genetic markers: a largely untapped resource for applied conservation and evolution. Evolutionary Applications 3, 244-262.

Winker, H., Kerwath, S.E., Attwood, C.G., 2013. Comparison of two approaches to standardize catchper-unit-effort for targeting behaviour in a multispecies hand-line fishery. Fisheries Research 139, 118-131.

Winker, K., 2009. Reuniting phenotype and genotype in biodiversity research. BioScience 59, 657665.

Worm, B., Hilborn, R., Baum, J.K., Branch, T.A., Collie, J.S., Costello, C., Fogarty, M.J., Fulton, E.A., Hutchings, J.A., Jennings, S., Jensen, O.P., Lotze, H.K., Mace, P.M., McClanahan, T.R., Minto, C., Palumbi, S.R., Parma, A.M., Ricard, D., Rosenberg, A.A., Watson, R., Zeller, D., 2009. Rebuilding Global Fisheries. Science 325, 578-585.

Yearsley, R.D., Jones, C.L., Britz, P.J., Vine, N.G., 2011. Integrated culture of silver kob Argyrosomus inodorus and bloodworm Arenicola loveni loveni in abalone farm effluent. African Journal of Marine Science 33, 223-228.

Yemane, D., Field, J.G., Griffiths, M.H., 2004. Effects of fishing on the size and dominance structure of linefish of the Cape region, South Africa. African Journal of Marine Science 26, 161-177. 